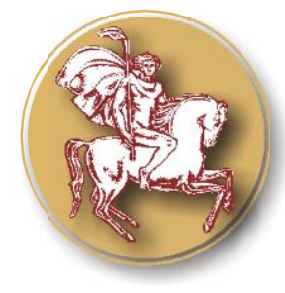

Trakia Journal of Sciences, No 4, pp 302-308, 2021

Copyright (C) 2021 Trakia University

Available online at:

http://www.uni-sz.bg

ISSN 1313-3551 (online)

doi:10.15547/tjs.2021.04.003

\title{
HOW DO DIFFERENT SOURCES CONTRIBUTE TO POPULATION EXPOSURE TO KEY AIR POLLUTANTS IN BULGARIA
}

\author{
D. Tsanova*, T. Vekov, A. Seizov, K. Statev \\ Department of Public Health Sciences, Faculty of Public Health, Medical University - Pleven, \\ Pleven, Bulgaria
}

\begin{abstract}
Air pollution is an important risk factor that has a significant impact on public health, especially in urban areas. The study aims to analyse the air pollution in Bulgaria and the main sources of pollution. Descriptive epidemiologic study design has been used to analyse the trends in air pollution in Bulgaria. Available data from the world and national databases were used. The data provided by EEA show that fewer and fewer Bulgarians live in areas with concentrations higher than European standards, but the proportion of the population exposed to air pollution is still quite high. The trend is to decrease the proportion of the Bulgarian population using solid fuel but still, it is five times higher than European Union. In Bulgaria Agriculture is a serious source of PM as ammonia can be a reason for the formation of secondary particulates. Energy and transport are the biggest cause of air pollution in cities but the agricultural sector is also a significant source. The comparative analysis of leading causes of years of life lost due to premature death or disability, expressed with Disability-adjusted live years (DALY) between 2009 and 2019 shows a slight improvement - the air pollution changes its position and falls to the eighth place among the tenth leading risk factors. Reducing the burden of disease due to poor air quality is an important goal for Bulgaria to achieve.
\end{abstract}

Key words: Bulgaria, air, pollutant, source

\section{INTRODUCTION}

Air pollution hurts human health, most often affects the functions of the respiratory, cardiovascular, and immune systems, leading to increased morbidity and reduced life expectancy (1-3). Poor air quality is a global threat leading to large impacts on human health and ecosystems. Emissions and concentrations have increased in many areas worldwide. Air pollution is one of the leading causes of premature death and is the largest single environmental risk factor. Cardiovascular diseases are the most common reason for premature death attributable to air pollution, followed by diseases of the respiratory system and lung cancer.

*Correspondence to: Dima Tsanova, 1, Sv. Kliment Ohridski Str., 5800 Pleven, Bulgaria, phone: +35964884278,e-mail:d_krumova@abv.bg
Air pollution is an important risk factor that has a significant impact on public health, especially in urban areas. It has also serious economic impacts, decreasing life expectancy, increasing medical costs, and reducing productiveness. The estimates of the World Health Organisation (WHO) are that each year 4.2 million deaths occur because of exposure to ambient (outdoor) air pollution (1).

Air pollutants may have a natural, anthropogenic or mixed origin, depending on their sources or the sources of their precursors. WHO states that the three pollutants are the most harmful with a very strong relationship with poor health $(4,5)$ :

$>$ particulate matter with a diameter below $2.5 \mu \mathrm{m}\left(\mathrm{PM}_{2.5}\right)$

$>$ nitrogen dioxide $\left(\mathrm{NO}_{2}\right)$

$>$ ground-level ozone $\left(\mathrm{O}_{3}\right)$. 
The experts assess these three pollutants as the proxies for the whole air pollution although this event is a mixture of several pollutants and the effects due to one may be caused by others.

Air pollutants are two main types - primary or secondary. Primary pollutants are emitted into the atmosphere, secondary - formed in the atmosphere from precursor pollutants by chemical reactions and microphysical processes. Among the primary air pollutants, the most harmful to human health are particulate matter $(\mathrm{PM})$, nitrogen oxides $\left(\mathrm{NO}_{\mathrm{X}}\right)$ - nitrogen monoxide $(\mathrm{NO})$ and nitrogen dioxide $\left(\mathrm{NO}_{2}\right)$ and sulphur oxides $\left(\mathrm{SO}_{\mathrm{X}}\right)$.

Main secondary air pollutants are PM formed in the atmosphere, ozone and $\mathrm{NO}_{2}$.

$\mathrm{SO}_{2}, \mathrm{NO}_{\mathrm{X}}, \mathrm{NH}_{3}$, and VOCs are the main precursors for secondary PM. Gases $\mathrm{SO}_{2}, \mathrm{NO}_{\mathrm{X}}$ and $\mathrm{NH}_{3}$ interact in the atmosphere to make particulate sulphate $\left(\mathrm{SO}_{4}{ }^{2-}\right)$, nitrate $\left(\mathrm{NO}_{3}{ }^{-}\right)$and ammonium $\left(\mathrm{NH}_{4}{ }^{+}\right)$compounds. These compounds shape new particles in the air or condense on pre-existing ones to form secondary inorganic PM. Certain non-methane volatile organic compounds (NMVOCs) are oxidized to make less volatile compounds, which are the reason for secondary organic aerosols. Ground-level or tropospheric $\mathrm{O}_{3}$ is formed from chemical reactions with the very important role of the sunlight, following emissions of precursor gases - $\mathrm{NO}_{x}, \mathrm{NMVOCs}, \mathrm{CO}$, and $\mathrm{CH}_{4}$.

The study aims to analyse the air pollution in Bulgaria and the main sources of pollution.

\section{MATERIALS AND METHODS}

Descriptive epidemiologic study design has been used to analyse the trends in air pollution in Bulgaria. Available data from world and national databases were used - The European Clean Air Centre, Health and Environment Alliance, The European Environment Agency, National Air Quality Improvement Programme, national reports on the state and protection of the environment in the Republic of Bulgaria. For the
TSANOVA D., et al. needs of the study, a content analysis of the published data was made.

\section{DESCRIPTION AND RESULTS}

Air quality in Europa remains poor in many countries and regions, despite reductions in emissions and ambient concentrations (6). Europe's air quality has improved over time but, at the same time, it continues to give cause for severe concern. The European Environment Agency (EEA) states that in the EU every year there are more than 400000 premature deaths attributable to air pollution and poor air quality (7).

Bulgaria, as a former socialist country, has a history of strong industrialization, when little attention was paid to environmental issues. As one of Europe's poorer nations, it appears to have made limited progress in cleaning up its air. A 2011 report from the United Nations found that Bulgaria, along with Armenia and Romania, "lead the world in deaths from outdoor air pollution.” (8)

The data provided by EEA (9) show that fewer and fewer Bulgarians live in areas with concentrations higher than European standards, but the percentage of the population exposed to air pollution is still quite high. The exposure of the population from urban areas to nitrogen dioxide and tropospheric ozone decreases, but the exposure to fine particulate matter and benzo (a) pyrene remains high.

The most problematic areas in both the national and the local emission inventories are the residential heating emissions - $\mathrm{PM}_{10}, \mathrm{PM}_{2.5}$, polycyclic aromatic hydrocarbons $(\mathrm{PAH})$ and to a lesser extent - transport emissions $\left(\mathrm{NO}_{2}\right)$. Our top priority is to reduce air pollution from lowquality domestic heating. Over half of all Bulgarian households use solid fuels (coal, briquettes and wood) to heat their homes. (10) In cities like Sofia, this is the main cause of particulate matter $\left(\mathrm{PM}_{10}\right.$ and $\left.\mathrm{PM}_{2.5}\right)$. The trend is to decrease the proportion of Bulgarian population using solid fuel but still it is five times higher than European Union (Figure 1). (11) 
TSANOVA D., et al.

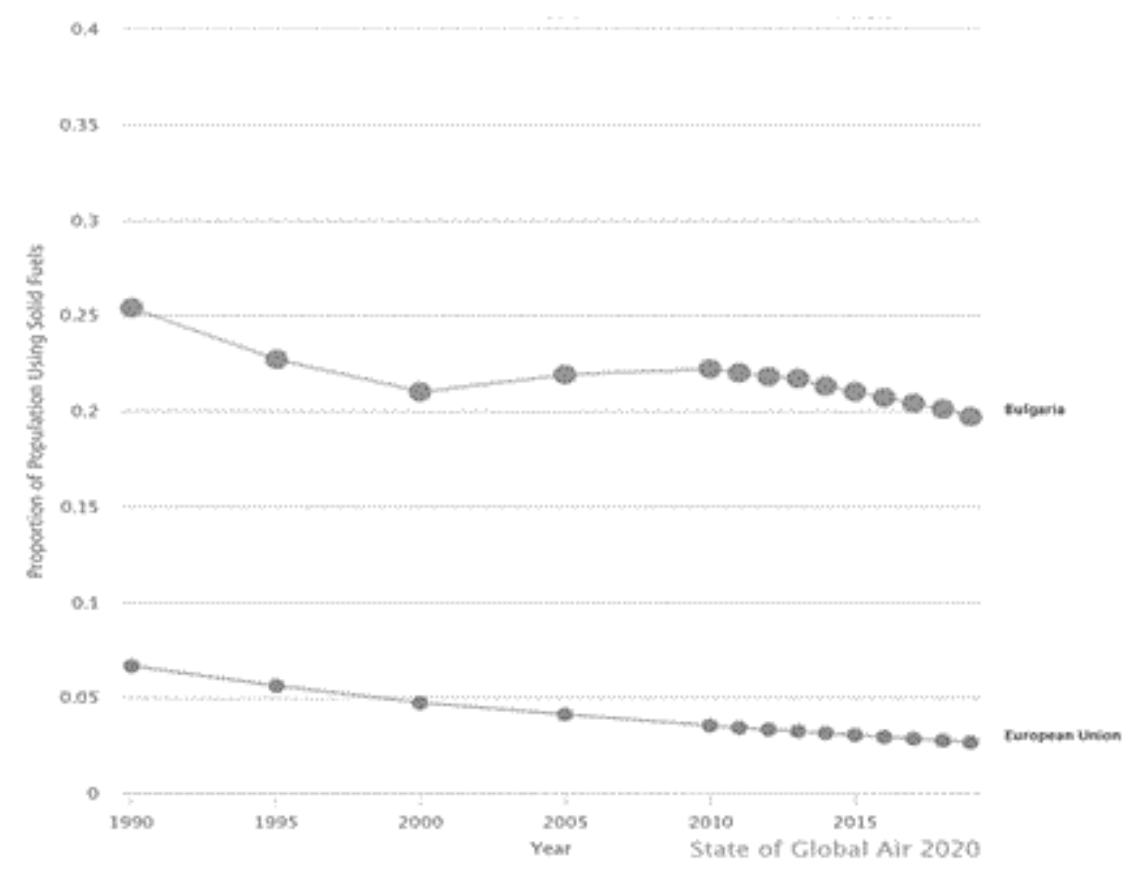

Figure 1. Proportion of population using solid fuels, EU and Bulgaria, 1990-2020, Source: https://www.stateofglobalair.org/data/\#/air/plot

The Global Burden of Disease Studies present a profile of each country with a comprehensive analysis of the country's public health. The Bulgarian profile (12) presents that air pollution is one of the leading causes of years of life lost due to premature death or disability, expressed with Disability-adjusted live years (DALY).
There are only two environmental risk factors among the tenth leading factors - air pollution and non-optimal temperature (Figure 2). The comparative analysis between 2009 and 2019 shows a slight tendency to improve - the factor changes its position and falls to the eighth place among the ten leading risk factors.

Metabolic risks

Environmental/occupational risks

Behavioral risks

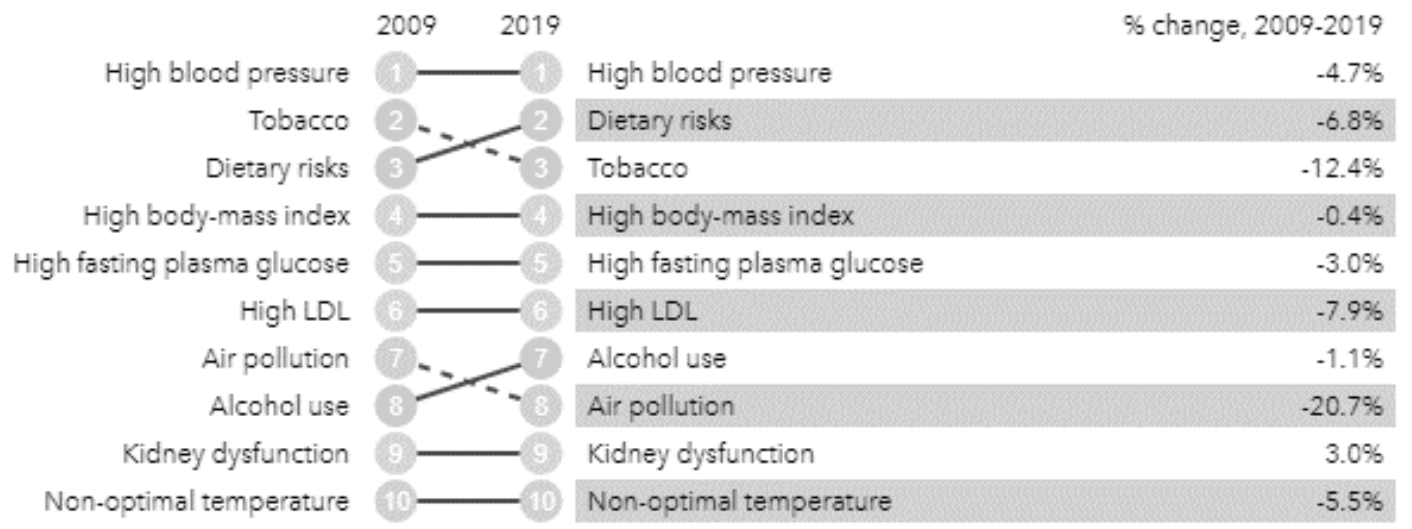

Figure 2. Top 10 risks contributing to total number of DALYs in 2019 and percent change 2009-2019, all ages combined, Bulgaria, Source: http://www.healthdata.org/bulgaria 
Analysing the effect of air pollution, using the number of years lost life (YLL) per 100000 inhabitants we find that the values for Bulgaria are above the European average, only Kosovo and Serbia in some respects have higher numbers (Table 1). The significant effect on public health,
TSANOVA D., et al. expressed by premature deaths and YLL, is observed in Central and Eastern Europe, especially Kosovo, Serbia, Bulgaria, Albania, and North Macedonia where the highest concentrations are also detected.

Table 1. YLL attributable to $\mathrm{PM}_{2.5}, \mathrm{NO}_{2}$ and $\mathrm{O}_{3}$ exposure in Bulgaria and other European countries, and EU-28, per 100000 inhabitants, 2016

\begin{tabular}{|l|l|l|l|}
\hline & $\mathbf{P M}_{\mathbf{2 . 5}}$ & $\mathbf{N O}_{\mathbf{2}}$ & $\mathbf{O}_{\mathbf{3}}$ \\
\hline Kosovo & 2100 & 14 & 51 \\
\hline Serbia & 1919 & 209 & 41 \\
\hline Bulgaria & $\mathbf{1 8 5 8}$ & $\mathbf{1 5 1}$ & $\mathbf{4 2}$ \\
\hline EU-28 & 800 & 100 & 30 \\
\hline Total & 900 & 100 & 30 \\
\hline
\end{tabular}

The sources of air pollution are different, but there are four main ones:

- mobile sources - cars, buses, planes, trucks, and trains

- $\quad$ stationary sources - power plants, oil refineries, industrial facilities, and factories

- $\quad$ area sources - urban areas, agricultural areas, wood burning fireplaces

- natural sources - wind-blown dust, wildfires, and volcanoes

Each pollutant has different sources. The European Clean Air Centre in State of air quality in Bulgaria (13) provides information about the main sources of air pollution (Table 2). Bulgaria's National Air Quality Improvement Programme also established that the principal source of primary $\mathrm{PM}_{10}$ emissions within all the municipalities was residential heating using thermally inefficient solid fuel appliances estimated to account for around $85 \%$ of $\mathrm{PM}_{10}$ emissions. Road transport - the exhaust emissions from vehicles - was identified as a further contributor and may be significant in larger cities (14). The programme acknowledged that big share of the population uses solid fuel for heating and that $\mathrm{PM}_{10}$ emissions from residential heating arise mainly from the burning of firewood and to a lesser extent of coal. Burning damp, unseasoned firewood, or coal having a high ash content and low calorific value, was highlighted as main contributors to high $\mathrm{PM}_{10}$ emissions; exacerbated if fuel is burned in old, inefficient stoves and boilers that represent the majority of such appliances used in Bulgaria (15).

Table 2. Main emission sources, 2018, The National Inventory of Emissions, 2020

\begin{tabular}{|l|l|l|}
\hline Pollutant & Main emission source & $\begin{array}{l}\text { Share in national } \\
\text { Emissions, \% }\end{array}$ \\
\hline $\mathrm{NO}_{\mathrm{X}}$ & $\begin{array}{l}\text { Road transport: Passenger cars and heavy- } \\
\text { duty vehicles and buses, combined }\end{array}$ & $34 \%$ \\
\hline $\mathrm{SO}_{\mathrm{X}}$ & Public electricity and heat production & $42 \%$ \\
\hline $\mathrm{PM}_{2.5}$ & Residential sector & $77 \%$ \\
\hline $\mathrm{PM}_{10}$ & Residential sector & $51 \%$ \\
\hline
\end{tabular}

Source: Center On Emission Inventories And Projections:

https://www.ceip.at/ms/ceip_home1/ceip_home/status_reporting/2020_submissions/ (16)

The European Environment Agency (EEA) summarizes the information about air quality in
Bulgaria (Table 3) - the country profile describes (9): 
TSANOVA D., et al.

- general information on air emissions and air quality

- the air quality situation of country based on reported air quality monitoring and measurement data
- the air pollutant emission based on the data reported by national authorities.

Table 3. Emission sources, Bulgaria, EEA, 2010-2018

\begin{tabular}{|l|l|l|l|l|l|l|}
\hline Pollutant & Agriculture & Energy supply & $\begin{array}{l}\text { Manufacturing and } \\
\text { extractive industry }\end{array}$ & Residential, commercial & Transport & Waste \\
\hline $\mathbf{N H}_{\mathbf{3}}$ & 83.21 & & 7.09 & 4.72 & 1.71 & 3.26 \\
\hline NMVOC & 16.84 & 4.37 & 36.91 & 26.57 & 12.82 & 2.49 \\
\hline NOx & 19.05 & 19.71 & 9.46 & 3.03 & 48.74 & - \\
\hline $\mathbf{P M}_{2.5}$ & 2.18 & 1.21 & 9.07 & 77.3 & 9.05 & 1.19 \\
\hline $\mathbf{S O}_{2}$ & 0.27 & 48.45 & 43.78 & 5.55 & - & - \\
\hline
\end{tabular}

Source: https://www.eea.europa.eu/themes/air/country-fact-sheets/2020-country-fact-sheets/bulgaria

The information related to $\mathrm{NH}_{3}$ emission shows that the main source is agriculture - respectively livestock (59.3\% of agriculture) and crops ( $40.7 \%$ of agriculture). For NMVOC the main source is Manufacturing and extractive industry, predominantly light industry $(75.88 \%$ of Man. and ext. industry). The main cause of $\mathrm{NOx}$ pollution is transport - road transport $(84.22 \%$ of transport), especially passenger cars. As regards $\mathrm{PM}_{2.5}$ the biggest role has Residential, commercial \& institutional establishments with $77.30 \%$ of total. The emissions of $\mathrm{SO}_{2}$ are mainly due to Energy supply, mostly by Energy production $(87.66 \%$ of Energy supply) and Manufacturing and extractive industry with $81.98 \%$ for Heavy industry.

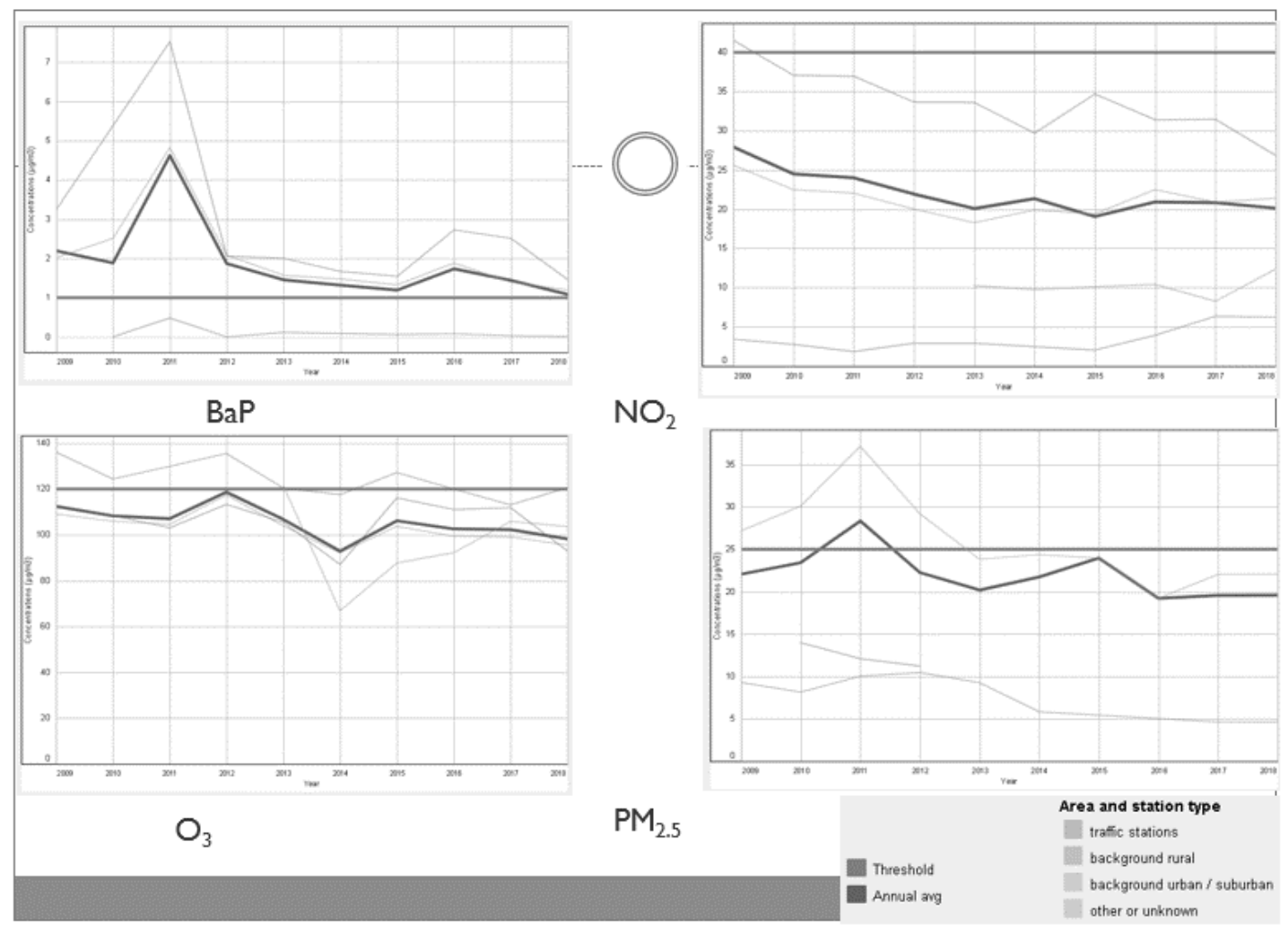

Figure 3. Air emissions, Bulgaria, 2009-2018, Source: European Environment Agency, https://www.eea.europa.eu/themes/air/country-fact-sheets/2020-country-fact-sheets/bulgaria 
Figure 3 shows the trend of $\mathrm{BaP}, \mathrm{NO}_{2}$, and $\mathrm{PM}_{2.5}$ annual mean concentration in Bulgaria compared to EU annual limited values; the trend of $\mathrm{O}_{3}$ percentile 93.15 concentrations in Bulgaria compared to the EU maximum daily 8-hours for human health target value and human health long-term objective $(120 \mu \mathrm{g} / \mathrm{m} 3)$. Only at traffic stations values are still above the thresholds. We must pay special attention to $\mathrm{BaP}$, which also has higher levels due to its carcinogenicity. The main sources of $\mathrm{BaP}$ are incomplete combustion of various fuels, domestic heating.

\section{CONCLUSIONS AND LESSONS}

Agriculture in Bulgaria is one of the most important sources of air pollution. Energy production and transport are the main sources in the cities, but in rural areas agriculture is the leading one, especially due to the formation of secondary pollutants from ammonia $(17,18)$.

Household air pollution is strongly related to socioeconomic development and its improvements, together with vast investments in clean energy can lead to the decline of the exposure and its associated burden of disease.

Reducing the burden of disease from air pollution is an important goal for Bulgaria to achieve. Recognizing the problem and its magnitude is an important step towards accomplishing a cleaner environment and a healthier society. As an EU member state, Bulgaria has to respect the relevant EU legislation. The responsible national authority for ensuring compliance is the Ministry of Environment and Waters. Air pollution is among the leading avoidable causes of disease and death globally. The key role of health authorities in raising awareness about the potential to save lives and reduce health costs, if air pollution is addressed. There is a need for cooperation between sectors and integration of health concerns into all national, regional and local air pollution-related policies.

The integrated multidisciplinary approach includes not only technological developments but structural changes and behavioural changes in order to achieve the needed holistic solutions. Efforts to achieve most of the Sustainable
Development Goals (SDGs) are linked directly or indirectly to mitigating air emissions and changes in atmospheric composition.

Air quality is strongly related to the Earth's climate and ecosystems worldwide. Many of the engines of air pollution (i.e. the burning of fossil fuels) are also sources of greenhouse gas emissions. Therefore, air pollution reduction policies offer a strategy that is "profitable" for climate and health, reducing the burden of diseases due to air pollution and contributing to the short-term and long-term mitigation of climate change.

\section{REFERENCES}

1. World Health Organization (WHO). Ambient (outdoor) air quality and health: Fact sheet. World Health Organization. http://www.who.int/mediacentre/factsheets/fs 313/en /. 2016.

2. World Health Organization (WHO). https://www.who.int/health-topics/airpollution\#tab=tab_2. 2021.

3. van den Hooven EH, de Kluizenaar Y, Pierik FH, Hofman A, van Ratingen SW, Zandveld PY, Mackenbach JP, Steegers EA, Miedema HM, Jaddoe VW. Air pollution, blood pressure, and the risk of hypertensive complications during pregnancy: The generation R study. Hypertension. 57(3):406412. http://dx.doi.org/10.1161/HYPERTENSION AHA.110.164087. 2011.

4. Dzhambov A, D Dimitrova, Exposures to road traffic, noise, and air pollution as risk factors for type 2 diabetes: A feasibility study in Bulgaria, Noise Health. 2016 May-Jun; 18(82): 133-142. doi: 10.4103/14631741.181996. 2016.

5. European Environment Agency (EEA), Air pollution sources, https://www.eea.europa.eu/themes/air/airpollution-sources-1/air-pollution-sources. 2021.

6. Krzyzanowski M, Vandenberg J, Stieb D. Perspectives on air quality policy issues in Europe and North America. Journal of Toxicology and Environmental Health. 68(1314):1057-1061. 
http://dx.doi.org/10.1080/1528739059093589 7. 2005.

7. European Environment Agency (EEA), Emissions of the main air pollutants in Europe, https://www.eea.europa.eu/data-andmaps/indicators/main-anthropogenic-airpollutant-emissions/assessment-6. 2021.

8. UNDP Human Development Report, UNPD, http://hdr.undp.org/sites/default/files/reports/ 271/hdr_2011_en_complete.pdf. 2011.

9. European Environment Agency (EEA), Bulgaria - Air pollution country fact sheet, https://www.eea.europa.eu/themes/air/countr $\mathrm{y}$-fact-sheets/2020-country-factsheets/bulgaria. 2021.

10.European Commission, The EU's 21st EcoInnovation Forum, 5-6 February, 2018, Sofia, Bulgaria, Press Release, https://ec.europa.eu/environment/ecoinnovati on2018/1st_forum/material/20180207_pressrelease-16th-european-forum-on-ecoinnovation_sofia_en.pdf. 2018.

11. The Health Effects Institute, The State of Global Air, https://www.stateofglobalair.org/data/\#/air/pl ot, 2021

12. Global Burden of Disease (GBD), The Institute for Health Metrics and Evaluation (IHME), http://www.healthdata.org/bulgaria. 2021.

13.European Clean Air Centre, State of air quality in Bulgaria: Overview, https://cleanaircentre.eu/wp-

content/uploads/2019/10/State-of-AQ-

Bulgaria.pdf. 2020.
TSANOVA D., et al.

14.Executive Environment Agency, National report on the state and protection of the environment in the Republic of Bulgaria, http://eea.government.bg/bg/soer/2018/air/em isii-na-vredni-veshtestva-vav-vazduha. 2021.

15. Health and Environment Alliance (HEAL), Air pollution and health in Bulgaria Facts, data and recommendations, https://envhealth.org/IMG/pdf/heal_briefing_air_bulgar ia_bgversion.pdf. 2014.

16. Center On Emission Inventories And Projections: $\quad 2020 \quad$ Reports, https://www.ceip.at/ms/ceip_home1/ceip_ho me/status_reporting/2020_submissions/. 2020.

17. Health Effects Institute (HEI). Traffic-related air pollution: A critical review of the literature on emissions, exposure, and health effects. Boston, MA: Health Effects Institute. https://www.healtheffects.org/publication/traf fic-related-air-pollution-critical-reviewliteratureemissions-exposure-and-health. 2010.

18.U.S. Environmental Protection Agency (USEPA). Integrated Science Assessment (ISA) for particulate matter. RTP, NC: U.S. Environmental Protection Agency, Office of Research and Development, National Center for Environmental Assessment. EPA/600/R08/139F.

https://cfpub.epa.gov/ncea/risk/recordisplay.c fm?deid=216546. 2009. 